\title{
Lanthanide complexes of macrocyclic derivatives useful for medical applications*
}

\author{
Rita Delgado ${ }^{1,2, \ddagger}$, Judite Costa $^{3}$, Krassimira P. Guerra ${ }^{1}$, and \\ Luís M. P. Lima ${ }^{1}$
}

\begin{abstract}
${ }^{1}$ Instituto de Tecnologia Química e Biológica, UNL, Apartado 127, 2781-901 Oeiras, Portugal; ${ }^{2}$ Instituto Superior Técnico, Dep. de Química, Av. Rovisco Pais, 1049-001 Lisboa, Portugal; ${ }^{3}$ Fac. de Farmácia da Universidade de Lisboa, Av. das Forças Armadas, 1649-019 Lisboa, Portugal
\end{abstract}

\begin{abstract}
The protonation constants of two series of tetraazamacrocyclic ligands with acetate and methylphosphonate pendant arms, as well as their stability constants with $\mathrm{Cu}^{2+}, \mathrm{La}^{3+}$, $\mathrm{Sm}^{3+}$, and $\mathrm{Ho}^{3+}$, were determined. All the values were determined in aqueous solution at $298.0 \mathrm{~K}$ and $0.10 \mathrm{~mol} \mathrm{dm}^{-3}$ in $\mathrm{N}\left(\mathrm{CH}_{3}\right)_{4} \mathrm{NO}_{3}$. In the first series, the effect of both types of pendant arms was observed by appending them in the same macrocyclic backbone, a 14-membered tetraazamacrocycle containing pyridine ( $\mathrm{ac}_{3}$ py $14, \mathrm{p}_{2}$ py 14 , and $\mathrm{p}_{3}$ py 14$)$. In the second series, two effects were taken into account, the increase of the cavity size of the macrocycle, from 12- to 14-membered, and the appending of acetate (dota, trita, and teta) or methylphosphonate (dotp, tritp, and tetp) arms. The ligands containing methylphosphonate arms have higher thermodynamic stability compared to the corresponding ones with acetate arms, especially in the series of compounds containing pyridine, even upon correction of the different basicity values of the ligands. On the other hand, the ligands with smaller macrocyclic cavity size, namely, dota and dotp, exhibit the largest values of stability constants. In contrast, $\mathrm{ac}_{3}$ py 14 presents low stability constants with lanthanides. An interpretation of these features based on the known adopted arrangement of dota and teta when free or coordinated with lanthanides is evaluated.
\end{abstract}

Keywords: stability constants; tetraazamacrocycles; lanthanide ions; methylphosphonate derivatives; acetate derivatives; speciation; metal complexes.

\section{INTRODUCTION}

Various types of imaging techniques are currently used for diagnosis of diseases. Among them, magnetic resonance imaging (MRI) and radiopharmaceuticals (drugs which incorporate a radioisotope) are powerful tools $[1,2]$. The design of new drugs that enhance the contrast between normal and diseased tissues and the simultaneous advances in pertinent technology strongly contributed to the recent developments in this area. Radiopharmaceuticals are also emergent drugs in tumor therapy, and new therapeutic radiopharmaceuticals have been recently prepared aiming to deliver large radiation doses to the diseased sites while sparing normal cells [3].

\footnotetext{
*Paper based on a presentation at the $11^{\text {th }}$ International Symposium on Solubility Phenomena (1 $1^{\text {th }}$ ISSP), Aveiro, Portugal, 25-29 July 2004. Other presentations are published in this issue, pp. 513-665.

¥Corresponding author: E-mail: delgado@itqb.unl.pt
} 
A number of macrocyclic chelators have been proposed as MRI contrast agents or as bifunctional agents for labeling antibodies and peptides with several radionuclides [1-5].

Since free Gd(III) ion (the most frequently used paramagnetic metal in MRI contrast agents) and free radionuclides are extremely toxic, it is required that they are administered to patients as chelates. Therefore, a crucial aspect for the success of these techniques is that the metal ions form thermodynamically stable and kinetically inert complexes with the selected compounds. Owing to their structural features, 12- to 14-membered tetraazamacrocyclic derivatives with acetate and/or methylphosphonate arms form metal complexes with the required properties for these applications [1-4]. Structural factors such as cavity size, rigidity of the macrocyclic backbone, and type and position of donor atoms play a significant role in the binding of macrocycles to metal cations [4,5]. The introduction of N-substituents, such as acetate and methylphosphonate, in the backbone of macrocycles increases the kinetic inertness of the metal complexes toward dissociation and leads to compounds with high stability constants. The compounds dota and teta form thermodynamically stable and kinetically inert complexes with di- and trivalent metal cations [4,5].

In spite of the recognized importance of critical assessment of thermodynamic data for the protonation constants of such ligands and its metal complexes, only few and very discrepant data are available, see, for instance, the published critical evaluation of stability constants for dota and teta [5]. Herein, we report the stability constant values for $\mathrm{Cu}^{2+}, \mathrm{La}^{3+}, \mathrm{Sm}^{3+}$, and $\mathrm{Ho}^{3+}$ complexes with two series of tetraazamacrocyclic ligands containing acetate or methylphosphonate pendant arms. In the first series, the effect of the two types of arms is observed by their inclusion in the same macrocyclic backbone, which is a 14-membered tetraazamacrocyclic compound containing pyridine, 3,7,11,17-tetraazabicyclo[11.3.1] heptadeca-1(17),13,15-triene, see Fig. 1. In the second series, two effects are taken into account: the increase of the size of the macrocyclic cavity, from 12- to 14-membered, and the appending of different arms containing additional donor atoms, such as acetate or methylphosphonate arms. The ligands dota (1,4,7,10-tetraazacyclododecane-1,4,7,10-tetraethanoic acid), trita (1,4,7,10-tetraazacyclotridecane-1,4,7,10-tetraethanoic acid), and teta (1,4,8,11-tetraazacyclotetradecane-1,4,8,11-tetraethanoic acid) were studied together with the corresponding methylphosphonate derivatives, dotp (1,4,7,10-tetraazacyclododecane-1,4,7,10-tetramethylenephosphonic acid), tritp (1,4,7,10-tetraazacyclotridecane-1,4,7,10-1,4,7,10-tetramethylenephosphonic acid), and tetp (1,4,8,11-tetraazacyclotetradecane-1,4,8,11-tetramethylenephosphonic acid), see Fig. 3.

\section{RESULTS AND DISCUSSION}

\section{4-Membered tetraazamacrocycles containing pyridine}

Table 1 shows the protonation constants of the first series of compounds studied, represented in Fig. 1, determined in aqueous solutions of tetramethylammonium nitrate $\left(\mathrm{NMe}_{4} \mathrm{NO}_{3}\right)$ at $298.0 \mathrm{~K}[6,7]$.

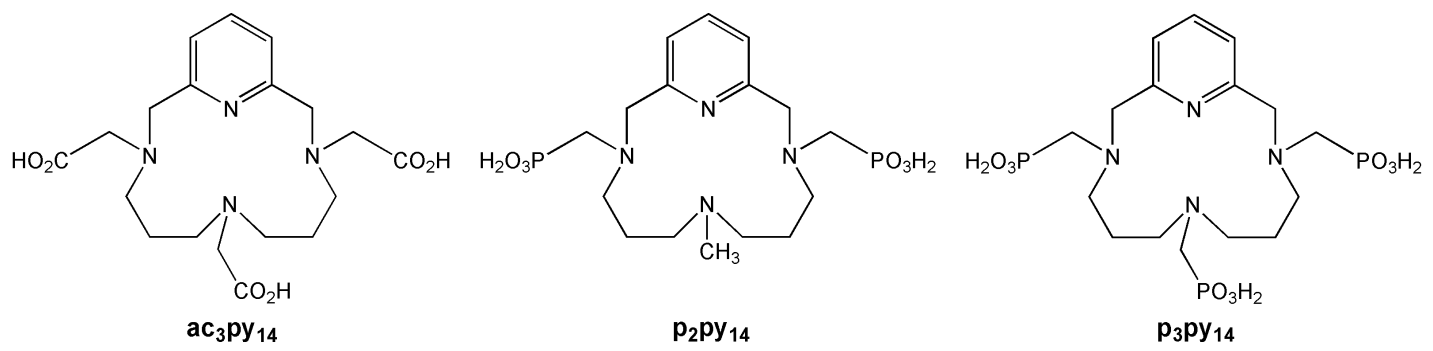

Fig. 1 Ligand structures of the 14-membered tetraazamacrocycles containing pyridine. 
Table 1 Protonation constants $\left(\log K_{i}^{\mathrm{H}}\right)^{\mathrm{a}}$ of ac ${ }_{3}$ py $14, \mathrm{p}_{2}$ py 14 , and $\mathrm{p}_{3}$ py 14 determined by potentiometry. $T=298.0 \mathrm{~K}$;

$I=0.10 \mathrm{~mol} \mathrm{dm}^{-3}$ in $\mathrm{NMe}_{4} \mathrm{NO}_{3}$.

\begin{tabular}{lccc}
\hline $\begin{array}{l}\text { Equilibrium } \\
\text { quotient }\end{array}$ & $\mathrm{ac}_{3}$ py $14^{\mathrm{b}}$ & $\mathrm{p}_{2}$ py14 & $\mathrm{p}_{3}$ py $14^{\mathrm{c}}$ \\
\hline$[\mathrm{HL}] /[\mathrm{L}] \times[\mathrm{H}]$ & 10.27 & 10.97 & 11.22 \\
{$\left[\mathrm{H}_{2} \mathrm{~L}\right] /[\mathrm{HL}] \times[\mathrm{H}]$} & 7.90 & 9.25 & 9.16 \\
{$\left[\mathrm{H}_{3} \mathrm{~L}\right] /\left[\mathrm{H}_{2} \mathrm{~L}\right] \times[\mathrm{H}]$} & 5.18 & 7.14 & 7.80 \\
{$\left[\mathrm{H}_{4} \mathrm{~L}\right] /\left[\mathrm{H}_{3} \mathrm{~L}\right] \times[\mathrm{H}]$} & 2.4 & 5.13 & 5.89 \\
{$\left[\mathrm{H}_{5} \mathrm{~L}\right] /\left[\mathrm{H}_{4} \mathrm{~L}\right] \times[\mathrm{H}]$} & - & 3.30 & 5.01 \\
{$\left[\mathrm{H}_{6} \mathrm{~L}\right] /\left[\mathrm{H}_{5} \mathrm{~L}\right] \times[\mathrm{H}]$} & & $<1$ & 3.82 \\
{$\left[\mathrm{H}_{4} \mathrm{~L}\right] /[\mathrm{L}] \times[\mathrm{H}]^{4}$} & 25.75 & 32.49 & 34.07 \\
{$\left[\mathrm{H}_{6} \mathrm{~L}\right] /[\mathrm{L}] \times[\mathrm{H}]^{6}$} & - & $<36$ & 42.90 \\
\hline
\end{tabular}

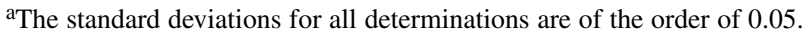

${ }^{\mathrm{b}}$ Ref. [8].

'Ref. [6].

The overall basicity of the compounds having methylphosphonate arms is very high compared with that of the $\mathrm{N}$-acetate derivative, $\mathrm{ac}_{3}$ py $14[6,8]$. This is explained by electrostatic effects and hydrogen-bonding formation [6]. Indeed, the electrostatic effect of the double negative charge on the phosphonate groups prevails over the inductive electron-withdrawal effect of these groups, making the nearby amine more basic [6,7]. The different overall basicity of the studied ligands has direct repercussion in their complexation properties and in their biological applications [7].

Stability constants for the complexes of these three ligands with $\mathrm{Cu}^{2+}$ and $\mathrm{La}^{3+}, \mathrm{Sm}^{3+}$ and $\mathrm{Ho}^{3+}$ in aqueous solutions of $\mathrm{NMe}_{4} \mathrm{NO}_{3}$ are compiled in Table 2. Figure 2 shows the species distribution diagrams for the systems $\mathrm{Ho}^{3+} / \mathrm{ac}_{3}$ py 14 and $\mathrm{Ho}^{3+} / \mathrm{p}_{3}$ py14, wherein the different behavior of the two ligands with the same metal ion is visualized.

As the ligands $\mathrm{p}_{2}$ py 14 and $\mathrm{p}_{3}$ py 14 form several protonated complexes with the studied metal ions, completely deprotonated ML complexes only exist as the main species at $\mathrm{pH}$ values around 8.5 , at which point the species MLOH start to be formed, see Fig. 2 for $\mathrm{p}_{3}$ py14.

The most interesting point concerning the values compiled in Table 2 is the different behavior observed for the lanthanide complexes of the compound containing acetate, $\mathrm{ac}_{3} \mathrm{py} 14$, and for those con-
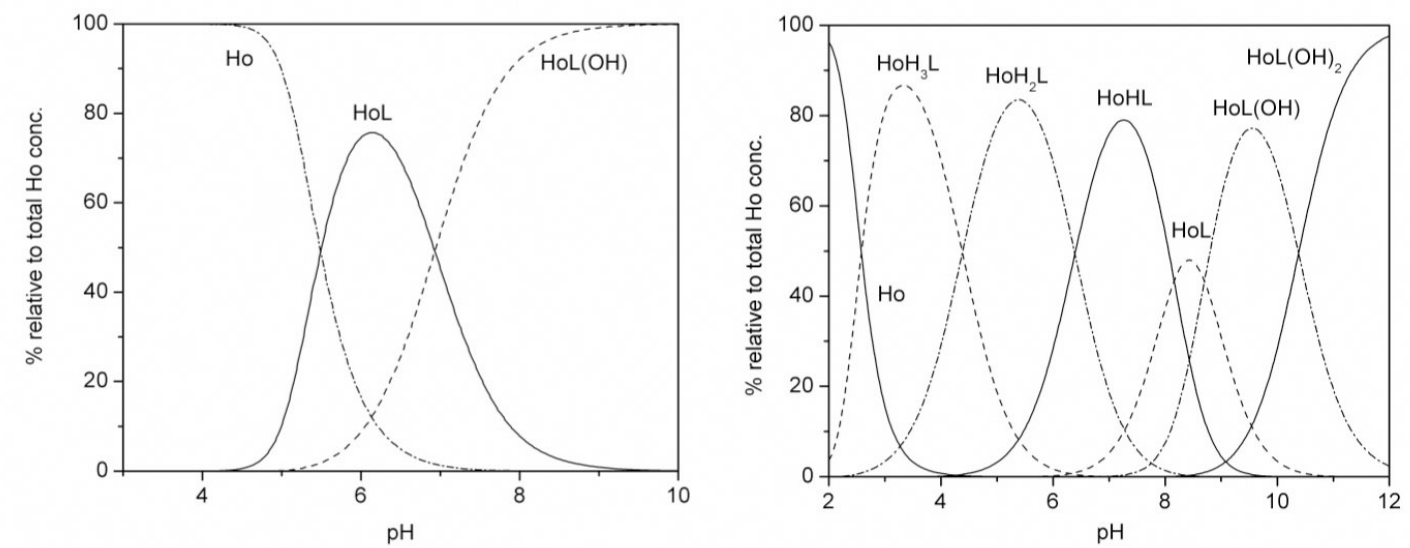

Fig. 2 Species distribution diagrams calculated for the 1:1 (M:L) complexes of $\mathrm{Ho}^{3+}$ with the ligands ac ${ }_{3}$ pyl4 (left) and $\mathrm{p}_{3}$ py14 (right), $\mathrm{C}_{\mathrm{L}}=\mathrm{C}_{\mathrm{M}}=1 \times 10^{-5} \mathrm{~mol} \mathrm{dm}^{-3}$. 
Table 2 Stability constants $\left(\log K_{\mathrm{M}_{\mathrm{m}} \mathrm{H}_{\mathrm{h}} \mathrm{L}_{\mathrm{l}}}\right)^{\mathrm{a}}$ of the complexes of $\mathrm{ac}_{3}$ py14, $\mathrm{p}_{2}$ py14 and $\mathrm{p}_{3}$ py14 with $\mathrm{Cu}^{2+}, \mathrm{La}^{3+}, \mathrm{Sm}^{3+}$, and $\mathrm{Ho}^{3+}$ metal ions. $T=298.0 \mathrm{~K}$, and $I=0.10 \mathrm{~mol} \mathrm{dm}^{-3}$ in $\mathrm{NMe}_{4} \mathrm{NO}_{3}$.

\begin{tabular}{|c|c|c|c|}
\hline Equilibrium $^{\mathrm{b}}$ & $\mathrm{ac}_{3} \mathrm{py} 14^{\mathrm{c}}$ & $\mathrm{p}_{2} \mathrm{py} 14^{\mathrm{d}}$ & $\mathrm{p}_{3} \mathrm{py} 14^{\mathrm{d}}$ \\
\hline $\mathrm{Cu}+\mathrm{L} \rightleftharpoons \mathrm{CuL}$ & 21.84 & 20.75 & 22.62 \\
\hline $\mathrm{CuL}+\mathrm{H} \rightleftharpoons \mathrm{CuHL}$ & 3.67 & 6.88 & 7.42 \\
\hline $\mathrm{CuHL}+\mathrm{H} \rightleftharpoons \mathrm{CuH}_{2} \mathrm{~L}$ & - & 5.63 & 6.65 \\
\hline $\mathrm{CuH}_{2} \mathrm{~L}+\mathrm{H} \rightleftharpoons \mathrm{CuH}_{3} \mathrm{~L}$ & - & - & 5.03 \\
\hline $\mathrm{CuLOH}+\mathrm{H} \rightleftharpoons \mathrm{CuL}$ & - & 11.64 & 11.10 \\
\hline $\mathrm{La}+\mathrm{L} \rightleftharpoons \mathrm{LaL}$ & 8.93 & 16.55 & 17.11 \\
\hline $\mathrm{LaL}+\mathrm{H} \rightleftharpoons \mathrm{LaHL}$ & - & 7.40 & 8.21 \\
\hline $\mathrm{LaHL}+\mathrm{H} \rightleftharpoons \mathrm{LaH}_{2} \mathrm{~L}$ & - & 5.41 & 6.26 \\
\hline $\mathrm{LaH}_{2} \mathrm{~L}+\mathrm{H} \rightleftharpoons \mathrm{LaH}_{3} \mathrm{~L}$ & - & 4.68 & 4.07 \\
\hline $\mathrm{LaH}_{3} \mathrm{~L}+\mathrm{H} \rightleftharpoons \mathrm{LaH}_{4} \mathrm{~L}$ & - & - & 3.74 \\
\hline $\mathrm{LaLOH}+\mathrm{H} \rightleftharpoons \mathrm{LaL}$ & 7.54 & 9.79 & 9.14 \\
\hline $\mathrm{Sm}+\mathrm{L} \rightleftharpoons \mathrm{SmL}$ & 9.78 & 17.26 & 18.87 \\
\hline $\mathrm{SmL}+\mathrm{H} \rightleftharpoons \mathrm{SmHL}$ & - & 7.46 & 8.17 \\
\hline $\mathrm{SmHL}+\mathrm{H} \rightleftharpoons \mathrm{SmH}_{2} \mathrm{~L}$ & - & 4.93 & 6.04 \\
\hline $\mathrm{SmH}_{2} \mathrm{~L}+\mathrm{H} \rightleftharpoons \mathrm{SmH}_{3} \mathrm{~L}$ & - & 4.07 & 3.77 \\
\hline $\mathrm{SmH}_{3} \mathrm{~L}+\mathrm{H} \rightleftharpoons \mathrm{SmH}_{4} \mathrm{~L}$ & - & - & 3.44 \\
\hline $\mathrm{SmLOH}+\mathrm{H} \rightleftharpoons \mathrm{SmL}$ & 6.99 & 9.42 & 8.89 \\
\hline $\mathrm{SmL}(\mathrm{OH})_{2}+\mathrm{H} \rightleftharpoons \mathrm{SmLOH}$ & - & 11.70 & 10.38 \\
\hline $\mathrm{Ho}+\mathrm{L} \rightleftharpoons \mathrm{HoL}$ & 10.31 & 16.84 & 19.16 \\
\hline $\mathrm{HoL}+\mathrm{H} \rightleftharpoons \mathrm{HoHL}$ & - & 6.97 & 8.16 \\
\hline $\mathrm{HoHL}+\mathrm{H} \rightleftharpoons \mathrm{HoH}_{2} \mathrm{~L}$ & - & 4.97 & 6.39 \\
\hline $\mathrm{HoH}_{2} \mathrm{~L}+\mathrm{H} \rightleftharpoons \mathrm{HoH}_{3} \mathrm{~L}$ & - & 4.11 & 4.38 \\
\hline $\mathrm{HoLOH}+\mathrm{H} \rightleftharpoons \mathrm{HoL}$ & 6.93 & 8.70 & 8.70 \\
\hline $\mathrm{HoL}(\mathrm{OH})_{2}+\mathrm{H} \rightleftharpoons \mathrm{HoLOH}$ & - & - & 10.38 \\
\hline
\end{tabular}

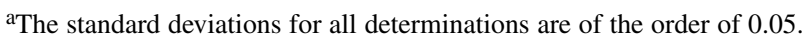
${ }^{b}$ For simplification, the charges of the species are not included in the equilibria reactions.

cValues for $\mathrm{Cu}^{2+}[8]$, for $\mathrm{Ln}^{3+}$ [7].

${ }^{\mathrm{d}}$ Values for $\mathrm{Cu}^{2+}[6], \mathrm{Ln}^{3+}$ [7].

taining phosphonate arms. The later ligands exhibit larger $K_{\mathrm{ML}}$ values for the complexes with lanthanide ions than the corresponding acetate derivative [6-8]. Differently, the $\mathrm{Ni}^{2+}, \mathrm{Cu}^{2+}$, and $\mathrm{Zn}^{2+}$ complexes of the same ligands present $K_{\mathrm{ML}}$ of the same order for the acetate and methylphosphonate derivatives, see in Table 2 the values for the $\mathrm{Cu}$ (II) complexes [6-8]. However, as the direct comparison of stability constants involving ligands with rather different overall basicity can lead to erroneous conclusions, because the competition of metals and proton for ligands is not taken into account, the $\mathrm{p} M$ values $(=-\log [\mathrm{M}])$, which are dependent of the protonation constants, were determined and collected in Table 3 [7]. It shows that the highest $\mathrm{p} M$ values were found for solutions containing the ligand with three methylphosphonate arms, immediately followed by those of the ligand with two methylphosphonate groups, and finally those of the compound containing acetate arms. This means that in these cases the $\mathrm{p} M$ and $\log K_{\mathrm{ML}}$ values follow the same trend. 
Table $3 \mathrm{p} M$ values $^{\mathrm{a}}$ determined for the complexes of $\mathrm{ac}_{3}$ py $14, \mathrm{p}_{2}$ py14, and $\mathrm{p}_{3}$ py 14 with $\mathrm{Cu}^{2+}$ and some trivalent metal ions, at $\mathrm{pH}=7.4$.

\begin{tabular}{lrrr}
\hline Metal ion & $\mathrm{ac}_{3}$ py 14 & $\mathrm{p}_{2}$ py 14 & $\mathrm{p}_{3}$ py 14 \\
\hline $\mathrm{Cu}^{2+}$ & 18.34 & 15.26 & 16.84 \\
$\mathrm{La}^{3+}$ & 5.69 & 11.23 & 11.87 \\
$\mathrm{Sm}^{3+}$ & 6.84 & 11.97 & 13.57 \\
$\mathrm{Ho}^{3+}$ & 7.42 & 11.37 & 13.89 \\
\hline
\end{tabular}

aValues calculated using Table 2 for $100 \%$ excess of free ligand, $\mathrm{C}_{\mathrm{L}}=2 \mathrm{C}_{\mathrm{M}}=1.0 \times 10^{-5} \mathrm{~mol} \mathrm{dm}^{-3}$.

\section{2- to 14-Membered tetraazamacrocycles}

The protonation constants for the second series of ligands (see Fig. 3) are collected in Table 4 [9-12]. In this series, the differences derived from the type of arms, which confer larger overall basicity values to the three compounds containing methylphosphonate arms, are also verified. This is shown by the species distribution diagrams for trita and tritp in Fig. 4. It is also observed that the 12-membered macrocyclic ligands, dota and dotp, present higher overall basicity values than the corresponding 13- and 14-membered macrocycles. This feature is contrary to what one should expect from the increase of the cavity size. Indeed, the electrostatic repulsions between ammonium ions inside the cavity decrease with the increase of the cavity size. However, in this series of compounds the last two amine centers of the macrocycles are protonated at very low $\mathrm{pH}$ values [9-11], and, therefore, the higher basicity values of dota and dotp should be explained by differences in hydrogen-bonding formation between the protonated nitrogen and the contiguous nitrogen atoms.
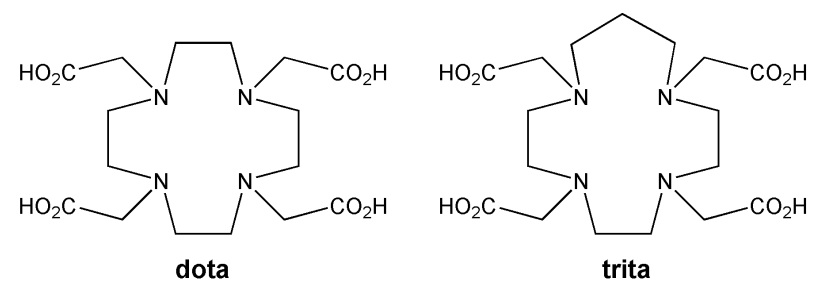<smiles>O=C(O)CCN(CCN(CCCN(CC(=O)O)CC(=O)O)CC(=O)O)CC(=O)O</smiles>
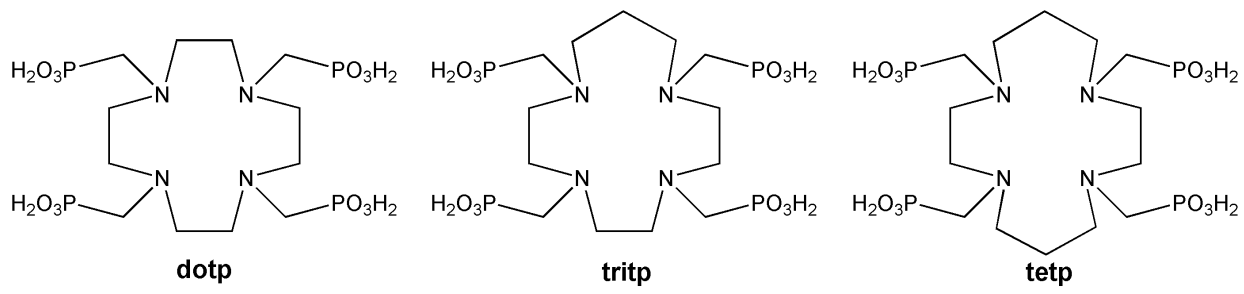

Fig. 3 Ligand structures of the 12- to 14-membered tetraazamacrocycles. 
Table 4 Protonation constants $\left(\log K_{i}^{\mathrm{H}}\right)^{\mathrm{a}}$ of dota, trita, teta, dotp, tritp, and tetp determined by potentiometry or ${ }^{31} \mathrm{P}$ NMR spectroscopy. $T=298.0 \mathrm{~K} ; I=0.10 \mathrm{~mol} \mathrm{dm}^{-3}$ in $\mathrm{NMe}_{4} \mathrm{NO}_{3}$.

\begin{tabular}{lcccccc}
\hline $\begin{array}{l}\text { Equilibrium } \\
\text { quotient }\end{array}$ & dota $^{\text {b }}$ & trita $^{\mathrm{b}}$ & teta $^{\mathrm{c}}$ & dotp $^{\mathrm{d}}$ & tritp $^{\mathrm{d}}$ & tetp $^{\mathrm{d}}$ \\
\hline$[\mathrm{HL}] /[\mathrm{L}] \times[\mathrm{H}]$ & 12.09 & 11.35 & 10.59 & $14.65^{\mathrm{e}}$ & $13.20^{\mathrm{e}}$ & $25.28^{\mathrm{e}, \mathrm{f}}$ \\
{$\left[\mathrm{H}_{2} \mathrm{~L}\right] /[\mathrm{HL}] \times[\mathrm{H}]$} & 9.76 & 9.73 & 10.08 & $12.40^{\mathrm{e}}$ & $12.46^{\mathrm{e}}$ & \\
{$\left[\mathrm{H}_{3} \mathrm{~L}\right] /\left[\mathrm{H}_{2} \mathrm{~L}\right] \times[\mathrm{H}]$} & 4.56 & 4.16 & 4.15 & 9.28 & 8.71 & 8.85 \\
{$\left[\mathrm{H}_{4} \mathrm{~L}\right] /\left[\mathrm{H}_{3} \mathrm{~L}\right] \times[\mathrm{H}]$} & 4.09 & 3.32 & 3.29 & 8.09 & 7.33 & 7.68 \\
{$\left[\mathrm{H}_{5} \mathrm{~L}\right] /\left[\mathrm{H}_{4} \mathrm{~L}\right] \times[\mathrm{H}]$} & - & - & 1.84 & 6.12 & 6.13 & 6.23 \\
{$\left[\mathrm{H}_{6} \mathrm{~L}\right] /\left[\mathrm{H}_{5} \mathrm{~L}\right] \times[\mathrm{H}]$} & - & - & - & 5.22 & 5.02 & 5.33 \\
{$\left[\mathrm{H}_{7} \mathrm{~L}\right] /\left[\mathrm{H}_{6} \mathrm{~L}\right] \times[\mathrm{H}]$} & - & - & - & - & 2.37 & 2.28 \\
{$\left[\mathrm{H}_{4} \mathrm{~L}\right] /[\mathrm{L}] \times[\mathrm{H}]^{4}$} & 30.49 & 28.56 & 28.11 & 44.42 & 41.70 & 41.81 \\
{$\left[\mathrm{H}_{6} \mathrm{~L}\right] /[\mathrm{L}] \times[\mathrm{H}]^{6}$} & - & - & - & 55.76 & 52.85 & 53.37 \\
\hline
\end{tabular}

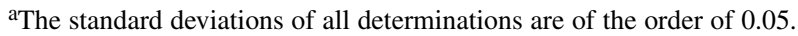

befs. [9,10].

'Determined before in $\mathrm{KNO}_{3}$ [9,10], and redetermined now in $\mathrm{NMe}_{4} \mathrm{NO}_{3}$ [12].

${ }^{\mathrm{d}}$ Determined before [11], and redetermined now [12].

e Determined with the HypNMR program [13] from ${ }^{31} \mathrm{P}$ NMR spectroscopic titration data.

${ }^{\mathrm{f}}$ The first two protonation constants are very close, hence only the constant for the equilibrium $\mathrm{H}_{2} \mathrm{~L} \rightleftharpoons \mathrm{L}+2 \mathrm{H}$ could be determined [12].
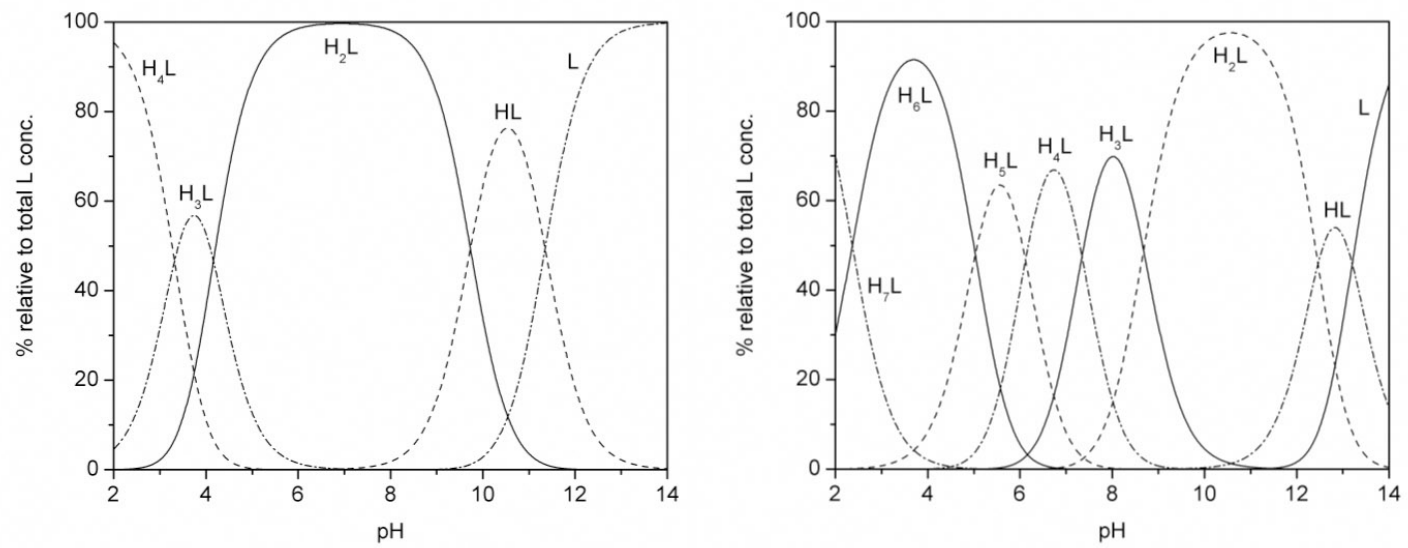

Fig. 4 Species distribution diagrams calculated for the ligands trita (left) and tritp (right), $C_{L}=1 \times 10^{-5} \mathrm{~mol} \mathrm{dm}^{-3}$.

The stability constants for the complexes of the six ligands with $\mathrm{Cu}^{2+}, \mathrm{La}^{3+}, \mathrm{Sm}^{3+}$, and $\mathrm{Ho}^{3+}$ in aqueous solutions of $\mathrm{NMe}_{4} \mathrm{NO}_{3}$ are compiled in Table 5 and the corresponding $\mathrm{p} M$ values in Table 6. Figure 5 shows the species distribution diagrams for $\mathrm{Sm}^{3+} /$ trita and $\mathrm{Sm}^{3+} /$ tritp where the different behavior of the two ligands toward the same lanthanide ion can be observed. 
Table 5 Stability constants $\left(\log K_{\mathrm{M}_{\mathrm{m}} \mathrm{H}_{\mathrm{h}} \mathrm{L}_{\mathrm{l}}}\right)^{\mathrm{a}}$ of the complexes of dota, trita, teta, dotp, tritp, and tetp with $\mathrm{Cu}^{2+}, \mathrm{La}^{3+}, \mathrm{Sm}^{3+}$, and $\mathrm{Ho}^{3+}$ metal ions. $T=298.0 \mathrm{~K} ; I=0.10 \mathrm{~mol} \mathrm{dm}^{-3}$ in $\mathrm{NMe}_{4} \mathrm{NO}_{3}$.

\begin{tabular}{|c|c|c|c|c|c|c|}
\hline Equilibrium $^{\mathrm{b}}$ & dota & trita & teta & dotp & $\operatorname{tritp}^{\mathrm{c}}$ & tetp $^{\mathrm{c}}$ \\
\hline $\mathrm{Cu}+\mathrm{L} \rightleftharpoons \mathrm{CuL}$ & $22.25^{\mathrm{d}}$ & $21.13^{\mathrm{d}}$ & $21.07^{\mathrm{e}}$ & $25.4^{\mathrm{f}}$ & 25.61 & 25.99 \\
\hline $\mathrm{CuL}+\mathrm{H} \rightleftharpoons \mathrm{CuHL}$ & $3.78^{\mathrm{d}}$ & $3.87^{\mathrm{d}}$ & $3.46^{\mathrm{e}}$ & $7.41^{\mathrm{f}}$ & 8.20 & 8.09 \\
\hline $\mathrm{CuHL}+\mathrm{H} \rightleftharpoons \mathrm{CuH}_{2} \mathrm{~L}$ & $3.70^{\mathrm{d}}$ & $2.90^{\mathrm{d}}$ & $2.35^{\mathrm{e}}$ & $6.42^{\mathrm{f}}$ & 7.13 & 6.93 \\
\hline $\mathrm{CuH}_{2} \mathrm{~L}+\mathrm{H} \rightleftharpoons \mathrm{CuH}_{3} \mathrm{~L}$ & - & - & - & $6.16^{\mathrm{f}}$ & 6.34 & 5.89 \\
\hline $\mathrm{CuH}_{3} \mathrm{~L}+\mathrm{H} \rightleftharpoons \mathrm{CuH}_{4} \mathrm{~L}$ & - & - & - & $4.58^{f}$ & 4.95 & 5.03 \\
\hline $\mathrm{CuLOH}+\mathrm{H} \rightleftharpoons \mathrm{CuL}$ & - & - & - & - & 12.00 & - \\
\hline $\mathrm{La}+\mathrm{L} \rightleftharpoons \mathrm{LaL}$ & $21.7 \mathrm{~g}$ & $14.52^{\mathrm{c}}$ & $12.15^{\mathrm{c}}$ & $27.6^{\mathrm{h}}$ & 21.00 & 18.02 \\
\hline $\mathrm{LaL}+\mathrm{H} \rightleftharpoons \mathrm{LaHL}$ & $2.5^{\mathrm{g}}$ & $6.16^{\mathrm{c}}$ & $12.13^{\mathrm{c}, \mathrm{i}}$ & $7.7^{\mathrm{h}}$ & 8.74 & 9.27 \\
\hline $\mathrm{LaHL}+\mathrm{H} \rightleftharpoons \mathrm{LaH}_{2} \mathrm{~L}$ & - & $3.94^{\mathrm{c}}$ & & $6.7^{\mathrm{h}}$ & 8.19 & 8.65 \\
\hline $\mathrm{LaH}_{2} \mathrm{~L}+\mathrm{H} \rightleftharpoons \mathrm{LaH}_{3} \mathrm{~L}$ & - & - & - & $5.6^{\mathrm{h}}$ & 7.28 & 8.28 \\
\hline $\mathrm{LaH}_{3} \mathrm{~L}+\mathrm{H} \rightleftharpoons \mathrm{LaH}_{4} \mathrm{~L}$ & - & - & - & $4.7^{\mathrm{h}}$ & 5.42 & 6.32 \\
\hline $\mathrm{LaH}_{4} \mathrm{~L}+\mathrm{H} \rightleftharpoons \mathrm{LaH}_{5} \mathrm{~L}$ & - & - & - & - & - & 3.37 \\
\hline $\mathrm{LaLOH}+\mathrm{H} \rightleftharpoons \mathrm{LaL}$ & - & - & $7.58^{\mathrm{c}}$ & - & 10.39 & 10.64 \\
\hline $\mathrm{Sm}+\mathrm{L} \rightleftharpoons \mathrm{SmL}$ & $23.0^{\mathrm{j}}$ & $16.69^{c}$ & $14.15^{\mathrm{c}}$ & $28.1^{\mathrm{h}}$ & 23.83 & 19.11 \\
\hline $\mathrm{SmL}+\mathrm{H} \rightleftharpoons \mathrm{SmHL}$ & - & $5.98^{\mathrm{c}}$ & $10.23^{\mathrm{c}, \mathrm{i}}$ & $7.6^{\mathrm{h}}$ & 8.70 & 9.63 \\
\hline $\mathrm{SmHL}+\mathrm{H} \rightleftharpoons \mathrm{SmH}_{2} \mathrm{~L}$ & - & - & & $6.3^{\mathrm{h}}$ & 8.13 & 8.58 \\
\hline $\mathrm{SmH}_{2} \mathrm{~L}+\mathrm{H} \rightleftharpoons \mathrm{SmH}_{3} \mathrm{~L}$ & - & - & - & $5.4^{\mathrm{h}}$ & 6.42 & 7.77 \\
\hline $\mathrm{SmH}_{3} \mathrm{~L}+\mathrm{H} \rightleftharpoons \mathrm{SmH}_{4} \mathrm{~L}$ & - & - & - & $4.4^{\mathrm{h}}$ & 4.31 & 6.15 \\
\hline $\mathrm{SmH}_{4} \mathrm{~L}+\mathrm{H} \rightleftharpoons \mathrm{SmH}_{5} \mathrm{~L}$ & - & - & - & - & - & 3.35 \\
\hline $\mathrm{SmLOH}+\mathrm{H} \rightleftharpoons \mathrm{SmL}$ & - & $8.02^{\mathrm{c}}$ & $7.37^{\mathrm{c}}$ & - & 8.96 & 8.78 \\
\hline $\mathrm{SmL}(\mathrm{OH})_{2}+\mathrm{H} \rightleftharpoons \mathrm{SmLOH}$ & - & - & $7.58^{\mathrm{c}}$ & - & - & - \\
\hline $\mathrm{Ho}+\mathrm{L} \rightleftharpoons \mathrm{HoL}$ & $24.8^{\mathrm{j}}$ & $17.38^{\mathrm{c}}$ & $15.78^{\mathrm{c}}$ & $29.2^{\mathrm{h}}$ & 24.07 & 20.03 \\
\hline $\mathrm{HoL}+\mathrm{H} \rightleftharpoons \mathrm{HoHL}$ & - & $5.62^{\mathrm{c}}$ & $8.84^{\mathrm{c}, \mathrm{i}}$ & $8.3^{\mathrm{h}}$ & 9.10 & 9.52 \\
\hline $\mathrm{HoHL}+\mathrm{H} \rightleftharpoons \mathrm{HoH}_{2} \mathrm{~L}$ & - & - & & $6.9^{\mathrm{h}}$ & 7.88 & 9.25 \\
\hline $\mathrm{HoH}_{2} \mathrm{~L}+\mathrm{H} \rightleftharpoons \mathrm{HoH}_{3} \mathrm{~L}$ & - & - & - & $5.6^{\mathrm{h}}$ & 6.48 & 7.58 \\
\hline $\mathrm{HoH}_{3} \mathrm{~L}+\mathrm{H} \rightleftharpoons \mathrm{HoH}_{4} \mathrm{~L}$ & - & - & - & $4.5^{\mathrm{h}}$ & 4.71 & 5.60 \\
\hline $\mathrm{HoH}_{4} \mathrm{~L}+\mathrm{H} \rightleftharpoons \mathrm{HoH}_{5} \mathrm{~L}$ & - & - & - & - & - & 3.10 \\
\hline $\mathrm{HoLOH}+\mathrm{H} \rightleftharpoons \mathrm{HoL}$ & - & $8.02^{\mathrm{c}}$ & $7.03^{\mathrm{c}}$ & - & 9.40 & 10.09 \\
\hline $\mathrm{HoL}(\mathrm{OH})_{2}+\mathrm{H} \rightleftharpoons \mathrm{HoLOH}$ & - & - & $7.36^{\mathrm{c}}$ & - & - & - \\
\hline
\end{tabular}

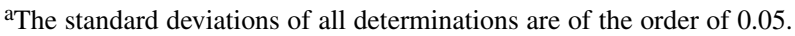

${ }^{b}$ For simplification, the charges of the species are not included in the equilibria reactions.

${ }^{\mathrm{c}}$ Ref. [12]

${ }^{\mathrm{d}}$ Refs. $[9,10]$.

e Determined before in $\mathrm{KNO}_{3}[9,10]$ and redetermined in $\mathrm{NMe}_{4} \mathrm{NO}_{3}[12]$.

${ }^{\mathrm{f}} I=1.0 \mathrm{~mol} \mathrm{dm}{ }^{-3}$ in $\mathrm{KNO}_{3}[14]$.

$\mathrm{g}_{I}=0.10 \mathrm{~mol} \mathrm{dm}^{-3}$ in $\mathrm{KCl}[15]$.

${ }^{\mathrm{h}}$ Ref. [16].

${ }^{\mathrm{i}}$ Corresponding to the global equilibrium $\mathrm{ML}+2 \mathrm{H} \rightleftharpoons \mathrm{MH}_{2} \mathrm{~L}$, with $\mathrm{L}=$ teta and $\mathrm{M}=\mathrm{La}^{3+}, \mathrm{Sm}^{3+}$, and $\mathrm{Ho}^{3+}$.

$\mathrm{j}_{I}=1 \mathrm{~mol} \mathrm{dm}^{-3}$ in $\mathrm{NaCl}[17]$. 
Table $6 \mathrm{p} M$ values $^{\mathrm{a}}$ determined for the complexes of dota, trita, teta, dotp, tritp, and tetp with $\mathrm{Cu}^{2+}$ and some trivalent metal ions, at $\mathrm{pH}=7.4$, based in the values of Table 5 .

\begin{tabular}{lrrrrrr}
\hline Metal ion & dota & trita & teta & dotp & tritp & \multicolumn{1}{c}{ tetp } \\
\hline $\mathrm{Cu}^{2+}$ & 15.19 & 14.05 & 15.19 & 17.96 & 14.19 & 14.45 \\
$\mathrm{La}^{3+}$ & 14.65 & 8.26 & 6.52 & 14.36 & 10.96 & 9.69 \\
$\mathrm{Sm}^{3+}$ & 16.25 & 10.50 & 8.71 & 14.76 & 13.51 & 10.65 \\
$\mathrm{Ho}^{3+}$ & 17.75 & 11.20 & 10.67 & 16.49 & 13.95 & 11.99 \\
\hline
\end{tabular}

avalues calculated for $100 \%$ excess of free ligand, $\mathrm{C}_{\mathrm{L}}=2 \mathrm{C}_{\mathrm{M}}=$ $2.0 \times 10^{-5} \mathrm{~mol} \mathrm{dm}^{-3}$.
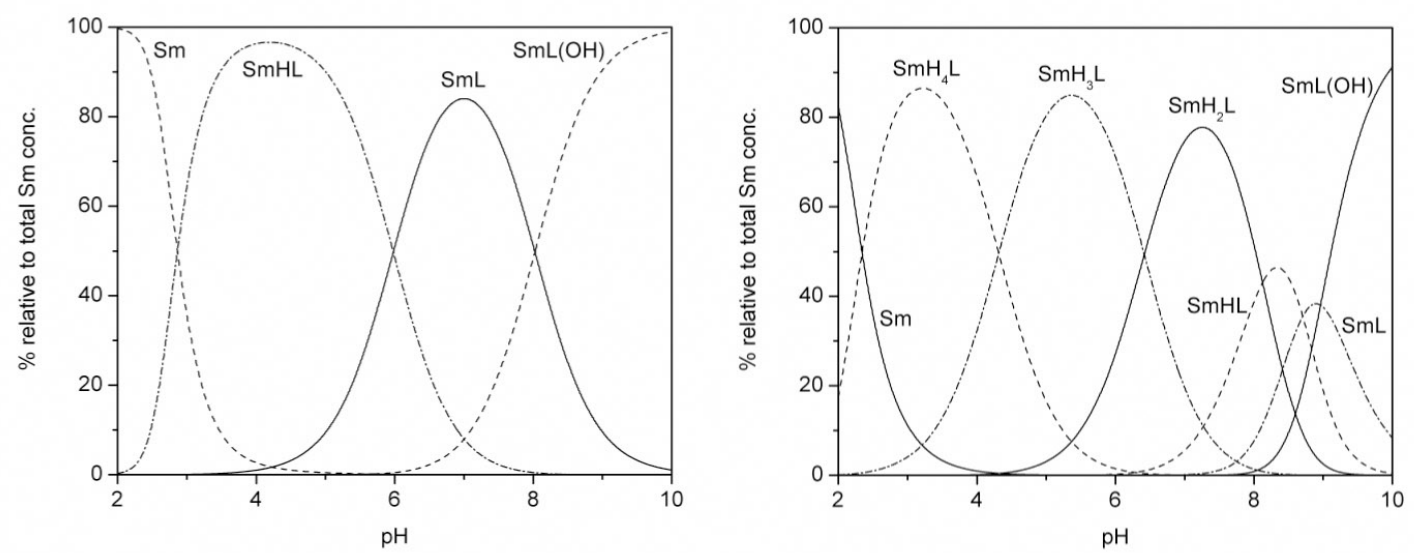

Fig. 5 Species distribution curves calculated for the 1:1 (M:L) complexes of $\mathrm{Sm}^{3+}$ with the ligands trita (left) and tritp (right), $\mathrm{C}_{\mathrm{L}}=\mathrm{C}_{\mathrm{M}}=1 \times 10^{-5} \mathrm{~mol} \mathrm{dm}^{-3}$.

The main feature to be emphasized for this series of ligands is the exceptionally high value of the ML stability constants of their complexes, especially those of dota and dotp. The distinct behavior of the $\mathrm{Cu}(\mathrm{II})$ and $\mathrm{Ln}$ (III) complexes of the compounds having acetate and methylphosphonate arms observed in the series of macrocycles containing pyridine, in which the $K_{\mathrm{ML}}$ and $\mathrm{p} M$ values are lower for the complexes of the ligand having acetate arms, is also perceived for this series, but with smaller differences (see Fig. 5). Indeed, the $\mathrm{p} L n$ values for trita and teta are lower than those for tritp and tetp, respectively, while similar values are determined for $\mathrm{pC} u$ of the four ligands. It should be noted that several discrepancies can be seen in the values for dota and dotp, certainly derived from differences in the accuracy of the various laboratories that performed the experiments [5], because we have not redetermined the values for those two ligands.

The most significant point to be stressed for this series of ligands is the decrease of the $K_{\mathrm{ML}}$ and $\mathrm{p} M$ values for the lanthanide complexes with the increase of the cavity size, see Tables 5 and 6 . These values decrease gradually from dota to teta and from dotp to tetp for the same metal ion. On the other hand, $\mathrm{pC} u$ is almost constant for the complexes of all the ligands, and the same is also verified for $\mathrm{pNi}$, at least for dota, trita, and teta $[9,10]$.

\section{CONCLUSIONS}

In general, the ligands studied in this work exhibit very high thermodynamic stability constants with the first-row transition-metal [6,8-10] and lanthanide ions [5,7,12,14-17], although the $K_{\mathrm{LnL}}$ and $\mathrm{p} L n$ values decrease with the increase of the number of atoms of the macrocyclic ring and for those including 
acetate arms. Therefore, the 12-membered macrocycles, dota and dotp, have the highest values of thermodynamic stability constants.

The complexes of $\mathrm{Cu}(\mathrm{II})$ and other divalent first-row transition-metal ions with all these ligands present very high stability. In spite of requiring special geometries on coordination, these metal ions only allow low coordination numbers, and all the ligands studied in this work can offer seven or eight donor atoms, more than such metals need. In these complexes, the metal center exhibits penta- or hexacoordination spheres formed by the four nitrogen atoms of the macrocycle and two oxygen atoms from the arms, leaving one or more arms free and away from the metal. Some X-ray crystal structures confirm this point, such as in $\left[\mathrm{Cu}\left(\mathrm{ac}_{3} \text { py 14) }\right]^{-}[18]\right.$ and in $\left[\mathrm{Co}\left(\mathrm{ac}_{3}\right.\right.$ py 14)] [18], in which the six-coordination is completed with two oxygen atoms from contiguous acetate arms. This is also the case of $[\mathrm{M}(\mathrm{dota})]^{2-}$ and $[\mathrm{M}(\text { teta })]^{2-}\left(\mathrm{M}=\mathrm{Cu}^{2+}\right.$ or $\left.\mathrm{Ni}^{2+}\right)$ [19-22] where the metal centers adopt an octahedral geometry with the four nitrogen atoms of the macrocycle forming the equatorial plane and two oxygen atoms from opposed acetate arms occupying the axial positions, leaving the two other arms free and pointing away from the coordination sphere. In contrast, lanthanide ions generally form complexes with higher coordination numbers, such as in $\left[\mathrm{Eu}(\operatorname{dota})\left(\mathrm{H}_{2} \mathrm{O}\right)\right]^{-}[23]$ and $\left[\mathrm{Gd}(\operatorname{dota})\left(\mathrm{H}_{2} \mathrm{O}\right)\right]^{-}[24]$ or $[\mathrm{Tb}(\text { teta })]^{-}[25]$ and $[\mathrm{Eu}(\mathrm{teta})]^{-}[26]$, for which single-crystal X-ray structures were reported. In all these structures, the Ln center is accommodated in a well-suited cage formed by the macrocyclic backbone and the four acetate arms, all of them pointing to the same side of the ring. In these four structures, the metal is coordinated to the four nitrogen atoms of the ring and to one oxygen atom of each acetate arm. In both complexes with dota, the square antiprismatic arrangement of the eight coordinated atoms from the ligand is capped by the water molecule. The complexes of teta are eight-coordinated by the donor atoms of the ligand without the apical water molecule, forming very distorted dodecahedrons. These compact structures are likely to be adopted in solution, especially for the dota complexes, conferring very high stability to the complexes [4].

In spite of the similar structures adopted by the lanthanide complexes of dota and teta in the solid state and in solution, the thermodynamic stability values of the dota complexes are about nine log units higher than those of teta. Kinetically, both $[\operatorname{Ln}(\operatorname{dota})]^{-}$and $[\operatorname{Ln}(\text { teta })]^{-}$complexes are slow to form and to dissociate [27].

The reason for the different thermodynamic behavior of the lanthanide complexes of dota and teta seems to be more related to differences in the structures adopted by the free ligands than to differences in the structures of their complexes, as suggested by studies of molecular mechanics/dynamics [27]. Indeed, in the structure of free dota, the macrocycle adopts an arrangement which is very similar to that of the Ln complexes, meaning that the four acetate arms have a syn configuration in relation to the plane formed by the four nitrogen atoms of the macrocycle [28]. This indicates that dota has a preorganized structure and, therefore, only a limited reorganization of the ligand is necessary for the complexation with lanthanides. By contrast, free teta adopts an arrangement where two pairs of adjacent acetate arms have anti configuration $[29,30]$, and upon lanthanide complexation, the ligand needs to be completely rearranged in such a way that the four acetate arms adopt a syn configuration. These features are confirmed by molecular mechanics/dynamics studies in vacuum and in aqueous environment [27] that showed that teta, which has the larger macrocyclic cavity, can be considered more flexible than dota, which presents greater ligand constraint energy. This constraint energy is only partly compensated by the favored cation-ligand interaction energy, resulting in an overall less stable intermediate and final complex formation [27].

On the other hand, the present study showed that the ligands with methylphosphonate arms have slightly higher thermodynamic stability compared to the corresponding ones with acetate arms, even upon correction of the different overall basicity of the ligands. However, this feature does not seem to be the most important factor in biological experiments, where the acetate derivatives exhibit the best performance [12].

Some drawbacks still remain for the main medical applications of dota or dotp. They present very high values of stability constants, but do not show metal selectivity. Additionally, the formation of com- 
plexes is kinetically slow, which prevents certain uses as radiopharmaceuticals. Nevertheless, the lanthanide complexes of dota and dotp, and a variety of their $\mathrm{C}$ - and N-derivatives, are used as MRI contrast agents and as bifunctional chelates in tumor therapy [1-5], but the drawbacks justify the intense research in this area and the continuous design of new and better synthetic candidates.

\section{ACKNOWLEDGMENTS}

The authors acknowledge the financial support from Fundação para a Ciência e a Tecnologia (FCT) and POCTI, with co-participation of the European Community fund FEDER (Project no. POCTI/2000/CBO/35859). K.P.G. also acknowledges FCT for the grant (SFRH/BD/6492/2001). The authors are also grateful to M. P. Campello for the help in the beginning of this work.

\section{REFERENCES}

1. P. Caravan, J. E. Ellison, T. J. McMurry, R. B. Lauffer. Chem. Rev. 99, 2293-2352 (1999).

2. S. Liu and D. S. Edwards. Bioconj. Chem. 12, 7-34 (2001).

3. W. A. Volkert and T. J. Hoffman. Chem. Rev. 9, 2269-2292 (1999).

4. A. Bianchi, L. Calabi, F. Corana, S. Fontana, P. Losi, A. Maiocchi, L. Paleari, B. Valtancoli. Coord. Chem. Rev. 204, 309-393 (2000).

5. G. Anderegg, F. Arnaud-Neu, R. Delgado, J. Felcman, K. Popov. Pure Appl. Chem. (2005). In press.

6. K. P. Guerra, R. Delgado, L. M. P. Lima, M. G. B. Drew, Vítor Félix. Dalton Trans. 1812-1822 (2004).

7. F. Marques, K. P. Guerra, L. Gano, J. Costa, M. P. Campello, L. M. P. Lima, R. Delgado, I. Santos. J. Biol. Inorg. Chem. 9, 859-872 (2004).

8. J. Costa, R. Delgado, M. G. B. Drew, V. Félix. Dalton Trans. 1063-1071 (1998).

9. R. Delgado and J. J. R. Fraústo da Silva. Talanta 29, 815-822 (1982).

10. S. Chaves, R. Delgado, J. J. R. Fraústo da Silva. Talanta 39, 249-254 (1992).

11. R. Delgado, L. C. Siegfried, T. A. Kaden. Helv. Chim. Acta 73, 140-148 (1990).

12. F. Marques, L. Gano, M. P. Campello, I. Santos, J. Costa, R. Delgado, L. M. P. Lima. Unpublished results.

13. C. Frassineti, S. Ghelli, P. Gans, A. Sabatini, M. S. Moruzzi, A. Vacca. Analytical Biochem. 231, 374-382 (1995).

14. L. D. Pettit and H. K. J. Powell. IUPAC Stability Constants Database, Academic Software, Timble, 2004. The values included are from T. Medved, M. Kabachnik et al. Izv. Akad. Nauk (USSR) 9, 2103 (1988).

15. E. T. Clarke and A. E. Martell. Inorg. Chim. Acta 190, 37-46 (1991).

16. A. D. Sherry, J. Ren, J. Huskens, E. Brücher, É. Tóth, C. F. C. G. Geraldes, M. M. C. A. Castro, W. P. Cacheris. Inorg. Chem. 35, 4604-4612 (1996).

17. W. P. Cacheris, S. K. Nickle, A. D. Sherry. Inorg. Chem. 26, 958-960 (1987).

18. J. Costa, R. Delgado, M. G. B. Drew, V. Félix, R. T. Henriques, J. C. Waerenborgh. J. Chem. Soc., Dalton Trans. 3253-3265 (1999).

19. A. Riesen, M. Zehnder, T. A. Kaden. J. Chem. Soc., Chem. Commun. 1336-1338 (1985).

20. A. Riesen, M. Zehnder, T. A. Kaden. Helv. Chim. Acta 69, 2067-2073 (1986).

21. A. Riesen, M. Zehnder, T. A. Kaden. Acta Crystallogr. C44, 1740-1742 (1988).

22. A. Riesen, M. Zehnder, T. A. Kaden. Helv. Chim. Acta 69, 2074-2080 (1986).

23. M. K. Moi, M. Yanuck, S. V. Deshpande, H. Hope, S. J. DeNardo, C. F. Mears. Inorg. Chem. 26, 3458-3463 (1987).

24. M.-R. Spirlet, J. Rebizant, J. F. Desreux, M.-F. Loncin. Inorg. Chem. 23, 359-363 (1984). 
25. J.-P. Dubost, J.-M. Leger, M.-H. Langlois, D. Meyer, M. Schaefer. C. R. Acad. Sci. Paris 312, 349-354 (1991).

26. M.-R. Spirlet, J. Rebizant, M.-F. Loncin, J. F. Desreux. Inorg. Chem. 23, 4278-4283 (1984).

27. J.-G. Kang, M.-K. Na, S.-K. Yoon, Y. Sohn, Y.-D. Kim, I.-H. Suh. Inorg. Chim. Acta 310, 56-64 (2000).

28. C. A. Chang, Y.-L. Liu, C.-Y. Chen, X.-M. Chou. Inorg. Chem. 40, 3448-3455 (2001).

29. M.-R. Spirlet, J. Rebizant, P. P. Barthelemy, J. F. Desreux. J. Chem. Soc., Dalton Trans. 2477-2481 (1991).

30. M. R. Maurya, E. J. Zaluzec, S. F. Pavkovic, A. W. Herlinger. Inorg. Chem. 30, 3657-3662 (1991). 